\title{
UTILIZATION OF BLUETOOTH CONNECTIONS FOR ARDUINO BASED DOOR LOCK SECURITY TOOLS
}

\author{
Hafdiarsya Saiyar \\ Program Studi Teknologi Komputer \\ Universitas Bina Sarana Informatika \\ www.bsi.ac.id \\ hafdiarsya.hyr@bsi.ac.id
}

\begin{abstract}
Abstrak
Keamanan rumah merupakan hal yang wajib diperhatikan bagi setiap pemilik rumah. Apalagi saat Anda harus meninggalkan rumah dalam keadaan kosong untuk bekerja atau bahkan berlibur. Anda pasti khawatir akan adanya pencuri, perhiasan hilang, atau keamanan barang berharga lainnya. Maka dari itu penulis membuat alat keamanan kunci pintu dengan memanfaatkan koneksi Bluetooth dengan mikrokontroler Arduino uno.Metode penelitian yang digunakan adalah observasi langsung terhadap objek yang terpilih yaitu rumah penulis serta melakukan studi pustaka yang berkaitan dengan mikrokontroler Arduino Uno. Alat keamanan kunci pintu ini menggunakan Arduino Uno sebagai pusat pengolah data, karena mudah digunakan, dan yang paling penting dalam pengisian program, tidak memerlukan downloader layaknya mikrokontroler pada umunya. Arduino Uno ini berisi program khusus yang nantinya memberikan perintah ke Motor Servo untuk membuka dan mengunci pintu. Bukan hanya membuka dan mengunci pintu, tetapi alat ini juga dapat menggerakkan daun pintu tanpa kita pegang atau sentuh melainkan melalui Smartphone. Tujuan penelitian ini adalah Menghasilkan suatu alat yang dapat mempermudah dalam mengunci maupun membuka pintu dengan menggunakan Arduino melalui Smartphone Android dengan memanfaatkan koneksi Bluetooth.
\end{abstract}

Kata Kunci: Android, Arduino, Bluetooth, Motor Servo, Smartphone

\begin{abstract}
Home security is something that must be considered for every homeowner. Especially when you have to leave the house empty for work or even on vacation. You must be worried about thieves, lost jewelry, or the safety of other valuables. Therefore, the authors made a door lock security device by utilizing a Bluetooth connection with the Arduino Uno microcontroller. The research method used was direct observation of the selected object, namely the author's house, and conducting literature studies related to the Arduino Uno microcontroller. This door lock tool uses the Arduino Uno as a data processing center, because it is easy to use, and most importantly in the charging program, it does not require a download like a microcontroller in general. This Arduino Uno contains a special program that will give commands to the Servo Motor to open and open the door. Not only opening and opening doors, but this tool can also move the door without us holding or touching it but through a Smartphone. The purpose of this research is to produce a tool that can make it easier to manage or open doors using the Arduino via an Android smartphone using a Bluetooth connection.
\end{abstract}

Keywords: Android, Arduino, Bluetooth, Motor Servo, Smartphone.

\section{INTRODUCTION}

An electronic device control system is a simple system that is built to be able to turn off and turn on electronic devices, especially electronic devices around the house by taking advantage of current developments in information technology. Currently, security still uses manual keys (Yudhana et al., 2018), (Setyawati \& Darmawan, 2019) if the key is lost it will take time to open it and be able to use duplicate keys and can also be broken (Khalid et al., 2020). The research carried out aims to develop a system that can help urban communities (Handoko, 2017), (Handoko et al., 2018) in controlling electronic devices used daily in homes that include software and hardware with mobile devices as control.

This door lock security tool is designed to move using an Android Smartphone controller which has an application suitable for the 
movement of latch locks and door leaves. This door lock security tool uses Arduino Uno (Winardi, 2016), (Widcaksono \& Masyhadi, 2018) as a latch lock control system, and Bluetooth door leaves. The Bluetooth module functions as the receipt of commands sent via an Android Smartphone, the DC motor functions as a latch lock activator, and the door is controlled using an Android Smartphone and applications installed through the Playstore (Handayani \& Mardiana, 2018). The method used is an experimental method, the research conducted will focus on communication between smartphone devices and the Arduino Uno microcontroller (Widiyanto \& Nuryanto, 2016) (Nuryanto \& Widiyanto, 2016) via Bluetooth to control latch locks and door leaves.

\section{RESEARCH METHODS}

In collecting data and information, the author uses several research methods, including:

1. Observation Method

The author makes direct observations of the selected object, namely the author's house, where the author observes what tools are good to make it easier for the writer.

2. Literature study

To complete the required data, the authors conducted a literature study, namely by reading other data sources in campus libraries and offcampus libraries related to Microcontrollers and Arduino for planning tools.

\section{A. Block Diagram}

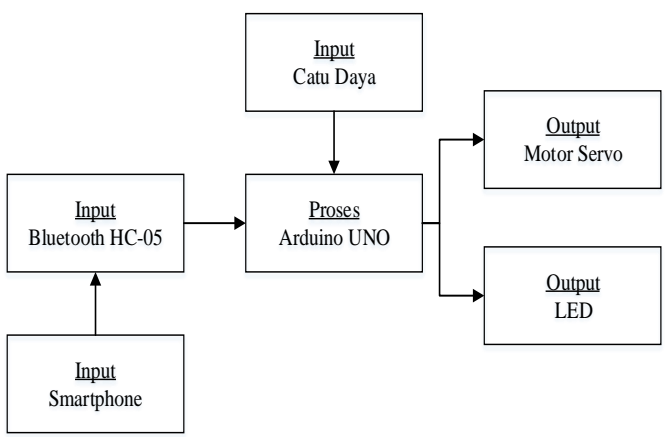

Figure 1. Block Diagram

Explanation of the block diagram tool Figure 1, as follows:

1. Input

This input component is an input component that will be processed. This input component consists of:

a. The power supply is a source of voltage to the circuit with a current amount of \pm 9 volts b. Bluetooth HC-05 functions as a connecting medium with a smartphone

c. Smartphones function as controllers or give commands to the circuit

2. Process

The process is the main component that functions as a data manager that is received from the input and will then produce the output. In this process, the writer uses an Arduino-based microcontroller.

3. Output

The output is the output of all processes that have been executed. The resulting output is:

a. Servo motor functions as a driver for the door latch.

b. The LED functions as an indicator of the input results so that we know whether the door is locked or not.

\section{A. Circuit Schematic}

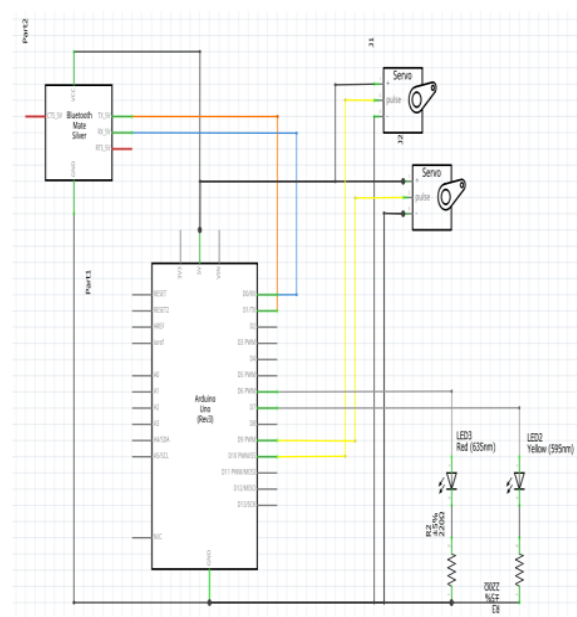

Figure 2. Circuit Schematic

Schematic explanation of the circuit of Figure 2, is a series of door lock security devices that use an Arduino-based microcontroller as a data processor. The Arduino uses ATMEGA 328P as a flash memory. Some of the pins used are:

1. Pins 9 and 10 are connected to the Servo Motor Pulse Pins

2. TX Pin is connected to Bluetooth RX Pin and vice versa RX Pinto Bluetooth TX Pin.

3. Pins 6 and 7 are connected to the positive pin of the LED

4. The $5 \mathrm{~V}$ pin is connected to the Bluetooth HC-05 VCC Pin and the Servo Motor Positive Pin

5. GND Pin is connected to Bluetooth GND Pin HC05 and Servo Motor Negative Pin

\section{A. How the Tool Works}

1. Power Supply 


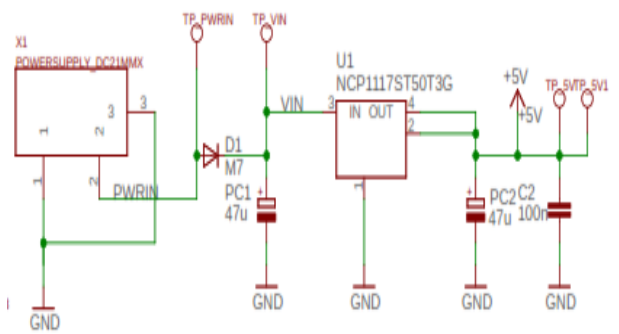

Figure 3. Power Supply Circuit

The power supply circuit in Figure 3 is one of the circuits found on the Arduino. The connector used to get an electric current is a $2.1 \mathrm{~mm}$ jack. After the connector is connected to $\mathrm{a} \pm 12 \mathrm{~V}$ voltage source, the incoming voltage passes through the diode, where the diode functions as a safety for the incoming electric current.

After passing through the diode, the current is passed to the NCP1117 regulator IC. The IC functions to reduce the current entering the Arduino. After the current is lowered, the current spreads across the pins which require an electric current through several capacitors. This capacitor functions as a filter for the incoming current so that the voltage noise is reduced.

1. Input circuit

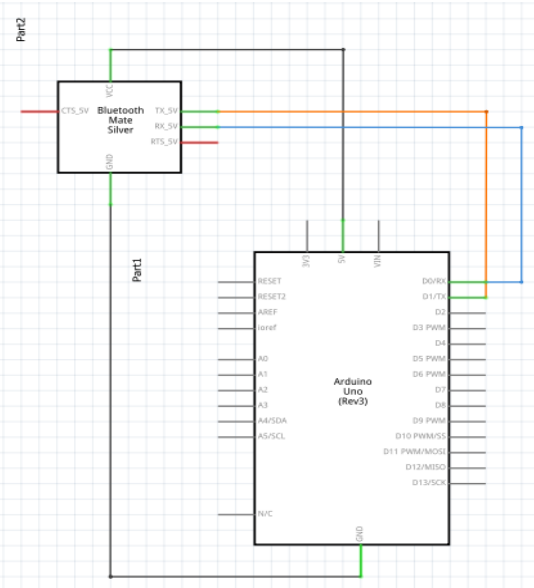

Figure 4. Input circuit

In Figure 4, there is an Arduino UNO R3 as a data or command processor and a Bluetooth HC-05 module as a signal sender to a Smartphone. The pins used in the input circuit consist of:

a. The TX Bluetooth HC-05 pin is connected to the Arduino RX pin so that the $\mathrm{HC}-05$ Bluetooth can send commands to the Arduino obtained via a Smartphone for later processing.

b. The RX Bluetooth HC-05 pin is connected to the c. Arduino TX Pin, so that Bluetooth HC-05 receives data in the form of commands that must be carried out by the Smartphone

d. The VCC Bluetooth HC-05 pin is connected to the Arduino $5 \mathrm{~V}$ pin so that the Bluetooth HC05 gets a $5 \mathrm{~V}$ voltage.

e. The HC-05 Bluetooth GND Pin is connected to the Arduino GND Pin. This pin is the ground voltage.

\section{Output circuit}

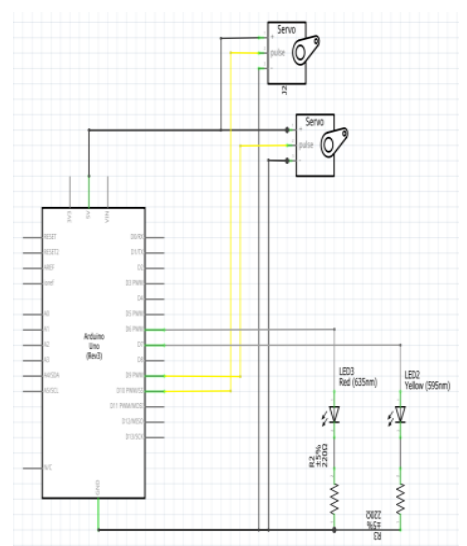

Figure 5. Output circuit

In the output series of Figure 5, there is an Arduino UNO R3 as a data processor, 2 servo motors to actuate the lock and door latch, and 2 LEDs as an indicator of whether the door is locked or open. The pulse pin on the servo motor that drives the latch lock is connected to pin 9 of the Arduino. At this pin, the start position of the servo motor is set at $90^{\circ}$ and that position is locked. And when you get the order to open the lock, the motor will rotate by $35^{\circ}$.

The servo motor pulse pin that moves the door is connected to pin 10 of the Arduino. At this pin, the start position of the servo motor is set to $15^{\mathrm{o}}$ and that position is locked. And when you get the command to open the lock, the motor will rotate as much as $150^{\circ}$. The + pin on the two servo motors is connected to the $5 \mathrm{~V}$ Arduino pin to get a voltage of $5 \mathrm{~V}$ and the - pin on the servo motor is connected to the Arduino GND pin to get a ground voltage. The red LED positive leg is connected to pin 6 of the Arduino. The pin is set so that the light turns on when the door is locked and off when it opens. While the positive leg of the yellow light is connected to pin 7 of the Arduino. The pin is set so that the light turns on when the door opens and turns off when the door is locked, and for the negative legs of the two LEDs, they are connected to the Arduino GND pin, where the pin provides ground voltage to the LED via a resistor. This 
resistor serves to block the electric current to the LED.

\section{A. Program Flowchart}

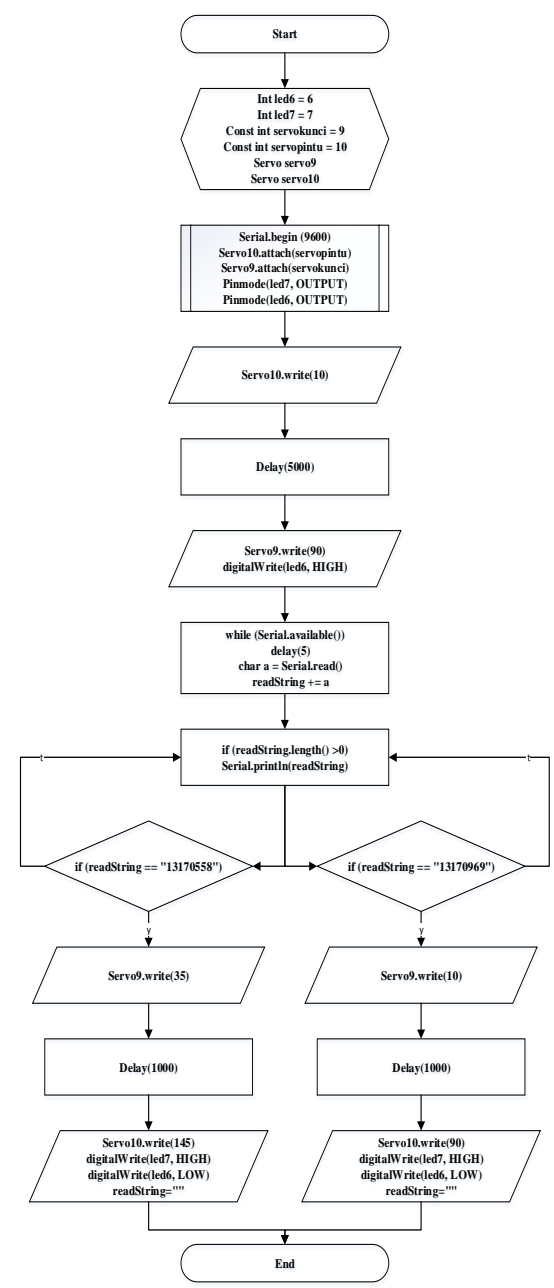

Figure 6. Flowchart Program

Explanation of the flowchart program in Figure 6, as follows: LED initialization, initialization from servo motor to latch lock as well as Servo servo10 is initialization from servo motor to door leaf. servo9.attach (9) functions to set the pin used by servo9, namely pin 9. Servo10.attach (10) functions to set the pin used by servo10, namely pin 10

1. Input

Input is a command given via a Smartphone. These commands use the looping function, namely if. When you want to open the door, the command used is if (readString $==$ "13170558"), meaning that when we input data 13170558, the door will open. And if you want to close the door, the command used is else if (readString == "13170969") which means that when we input data 13170969 , the door will be locked. readString itself functions to read whatever data we input.

\section{Main Program}

Serial.begin (9600) to determine the speed of sending and receiving data via the serial port at a rate of 9600 bits per second. When the serial port is unread, Serial.available 0 returns zero and is repeated with the while command. The character which is used to make the zero value has a value and that value can be read with the Serial.read () command. reading $+=$ functions so that the readString variable has a value greater than or equal to the character a.

3. Output

This output consists only of servo and led. pin This mode is used to set the pins used. For the pins used by led 6 and led7 to be output, the pinMode (led6, OUTPUT) and pinMode (led7, OUTPUT) commands are used for led7. To make the pin used by the led have a HIGH or LOW value, the digitalWrite command is used. When the condition led6 or led7 is off, then the command digitalWrite (led6 LOW) and digitalWrite (led7 LOW) are given for led7. And when led6 or led7 is on, the commands digitalWrite (led6 HIGH) and digitalWrite (led7 HIGH) are given for led7. To move or position the servo, give the command servo. write 0 . When the door is locked, the servo position is set with the commands servo9. write (90) and servo10. write (15) in the sense that servo 9 is set at $90^{\circ}$ and servo 10 is $10^{\circ}$. When open, the servo is set with the commands servo9. write (35) and servo10. write (150) in the sense that servo 9 is set at $35^{\circ}$ and servo 10 is $145^{\circ}$. delay (1000); is the time interval to process the next command for 1 second

\section{RESEARCH RESULTS AND DISCUSSION}

\section{A. Input Experiment Results}

The results of the input experiments obtained when testing the Arduino Bluetooth Controller application found on an Android smartphone are:

1. Make sure the application is installed then open it

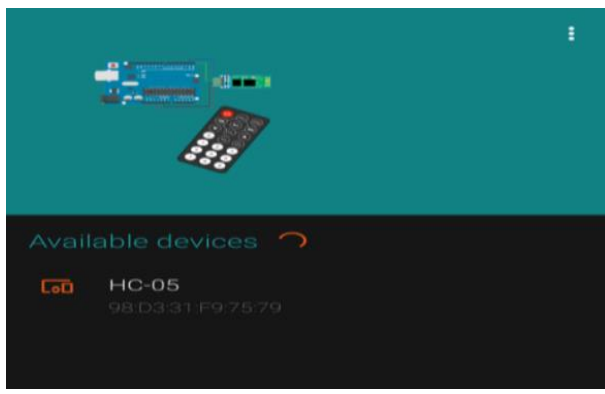

Figure 7. Main Application Display 
The explanation of Figure 7 is the Main Display of the Arduino-based door lock security application 2. Connect with HC-05 with password 1234

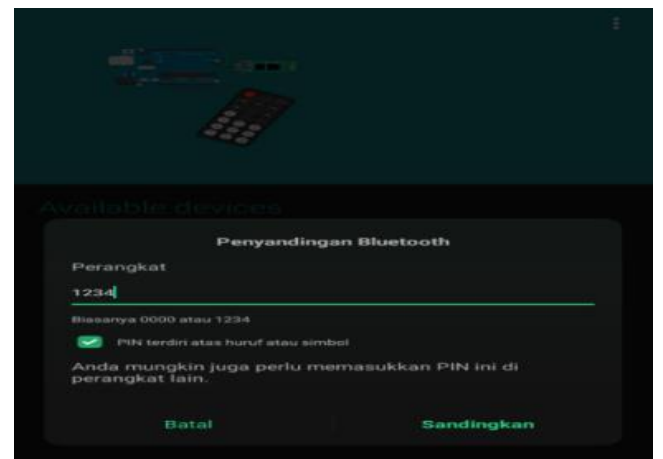

Figure 8. Connection with Bluetooth HC-05

The explanation of Figure 8 is an Arduino-based door lock security device connected to Bluetooth with a password of 1234 .

3. Once connected, select Switch mode

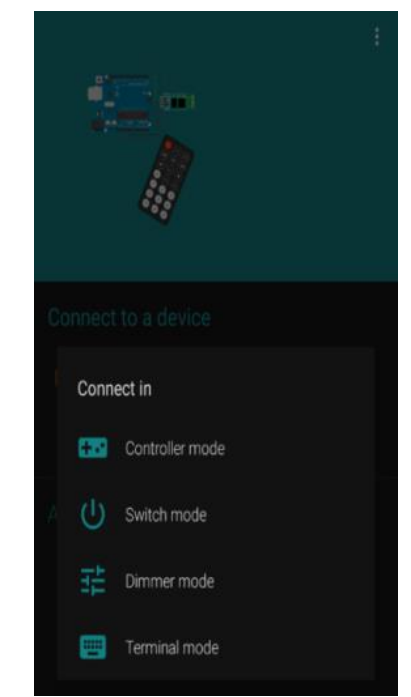

Figure 9. Connection Options

The explanation of Figure 9 is that select Switch mode to activate the door lock or open the door.

4. Click the settings or gear image and then adjust the input power according to the program

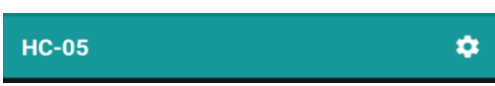

Figure 10. Settings button

The explanation of figure 10 is that the Bluetooth connection setting is active (on) or not (not).

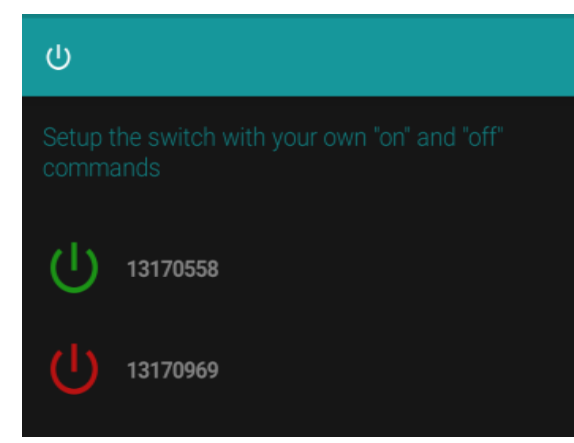

Figure 11. Setting Power Button Input Data

The explanation of Figure 11 is an Arduinobased door lock security device command to unlock the door (on) or lock the door (off).

5. When the power is off or red the door is locked.
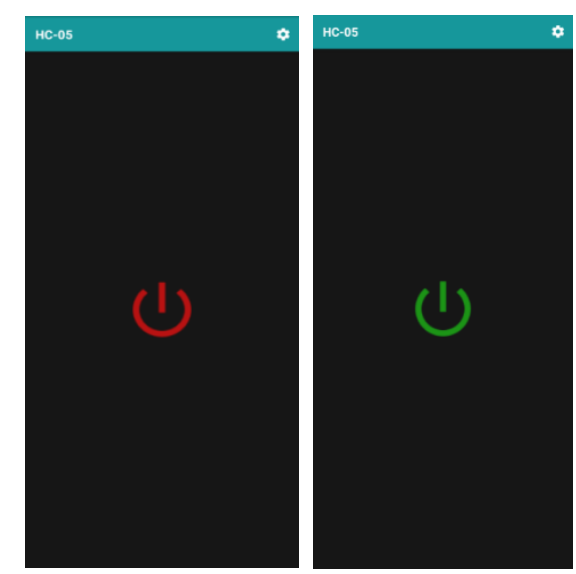

Figure 12. a) Power Off, and b) Power On

The explanation of Figure 12a is a display of the symbol indicator off, which means locking the door means the door is locked. When the power is on or the door opens green. The explanation of Figure $12 . b$ is a display of the symbol indicator on, that is, opening the door means the door is open.

\section{B. Experimental Results Output}

The experimental results obtained are:

1. The initial condition when the appliance is turned on, the door is locked and the red LED lights up.

2. When getting a command via a smartphone to open the door, the servo connected to the sliding key rotates first to unlock the lock then for about 1 second, the servo connected to the door leaf moves to open the door, and the yellow LED lights up.

3. When getting a command via a smartphone to wash the door, the servo connected to the door rotates first to close the door than about 1 second, the servo connected to the sliding lock 
rotates to lock the door and the red LED turns on.

\section{Overall Experiment}

The explanation in Table 1 is

1. 1, At Power On the output, is slide lock servo $35^{\circ}$, door leaf servo $145^{\circ}$, red led is off, yellow led is on and the door is open.

2. At the power of the output is a servo sliding lock $90^{\circ}$, door leaf servo $10^{\circ}$, red led on, yellow led off and the door locked.

Table 1. Overall Experiment Results

\begin{tabular}{ccccccc}
\hline & & \multicolumn{5}{c}{ Output } \\
\cline { 3 - 7 } No. & Button & $\begin{array}{c}\text { Sliding } \\
\text { Lock } \\
\text { Servo }\end{array}$ & $\begin{array}{c}\text { Leaf } \\
\text { Door } \\
\text { Servo }\end{array}$ & $\begin{array}{c}\text { Red } \\
\text { Led }\end{array}$ & $\begin{array}{c}\text { Yellow } \\
\text { Led }\end{array}$ & Condition \\
\hline 1 & $(1)$ & $35^{\circ}$ & $145^{\circ}$ & Off & On & Open door \\
\hline 2 & $(1)$ & $90^{\circ}$ & $10^{\circ}$ & On & Off & $\begin{array}{c}\text { Close } \\
\text { door }\end{array}$ \\
\hline
\end{tabular}

\section{CONCLUSIONS AND SUGGESTION}

\section{Conclusion}

The conclusion obtained from the experimental results of this Arduino-based door lock security device with a Bluetooth connection is that the device uses a Bluetooth connection to connect to a smartphone. Tool controlled via Android Smartphone. For the Smartphone to control the door lock security device, an application called the Arduino Bluetooth Controller is needed. Using 2 servo which functions to move the sliding lock and door leaf. The red LED is used as an indicator for the door when it is locked and the yellow LED as an indicator for the door is open

\section{Suggestion}

The advice needed in the development of this Arduino-based door lock security device with a Bluetooth connection is that the connection can be replaced with a WIFI connection. Security can be added with fingerprint, RFID or Electronic KTP, and so on. The tool made can be applied to the original object, namely the room door. Added LCD as an indicator in text form

\section{REFERENCE}

Handayani, Y. S., \& Mardiana, Y. (2018). Kendali Robot Bluetooth Dengan Smartphone Android Berbasis Arduino Uno. ILKOM Jurnal Ilmiah, 10(3), 331-337. https://doi.org/10.33096/ilkom.v10i3.363.3 31-337
Handoko, P. (2017). SISTEM KENDALI PERANGKAT ELEKTRONIKA MONOLITIK BERBASIS ARDUINO UNO R3. Seminar Nasional Sains Dan Teknologi 2017, 1-11. https://jurnal.umj.ac.id/index.php/semnaste $\mathrm{k} /$ article/view/2065

Handoko, P., Hermawan, H., \& Nasucha, M. (2018). Pengembangan Sistem Kendali Alat Elektronika Menggunakan Mikrokontroler Arduino Uno R3 dan Ethernet Shield dengan Antarmuka Berbasis Android. Dinamika Rekayasa, 14(2), 92-103. https://doi.org/10.20884/1.dr.2018.14.2.19 1

Khalid, Z., Achmady, S., \& Agustini, P. (2020). Otomatisasi Sistem Keamanan Kunci Lemari Menggunakan Sensor Sidik Jari Berbasis Arduino Uno. Jurnal TEKSAGRO, 1(1), 1-11. https://journal.lp2stm.or.id/index.php/TEKS AGRO/article/view/1

Nuryanto, N., \& Widiyanto, A. (2016). RANCANG BANGUN MOBILE ROBOT 2WD DENGAN 2 SENSOR SRF05 UNTUK MENENTUKAN ARAH BELOKAN. Seminar Nasional Teknologi Informasi Dan Multimedia 2016, 1-5.

Setyawati, M. G., \& Darmawan, A. (2019). Rancang Bangun Kunci Loker Masjid. Seminar Nasional Darmajaya.

https://jurnal.darmajaya.ac.id/index.php/PS ND/article/view/1947

Widcaksono, D., \& Masyhadi, M. (2018). RANCANG BANGUN SECURED DOOR AUTOMATIC SYSTEM UNTUK KEAMANAN RUMAH MENGGUNAKAN SMS BERBASIS ARDUINO. JURNAL KAJIAN TEKNIK ELEKTRO, 3(1), 5266.

http://journal.uta45jakarta.ac.id/index.php/J KTE/article/view/1060

Widiyanto, A., \& Nuryanto, N. (2016). Rancang Bangun Mobil Remote Control Android dengan Arduino. Creative Information Technology Journal, 3(1), 50-61. https://doi.org/10.24076/citec.2015v3i1.65

Winardi, S. (2016). RANCANG BANGUN SISTEM PENGAMAN PINTU RUMAH MENGGUNAKAN ANDROID BERBASIS ARDUINO UNO. $E$ NARODROID, 2(1). https://doi.org/10.31090/narodroid.v2i1.10 4

Yudhana, A., Sunardi, \& Priyatno. (2018). Perancangan Pengaman Pintu Rumah Berbasis Sidik Jari Menggunakan Metode Uml. Jurnal Teknologi, 10(2), 131-138. https://doi.org/10.24853/jurtek.10.2.131138 